\title{
Effect of Formulation on the Quality of Frozen Bread Dough
}

\author{
Myriam M. Salas-Mellado ${ }^{1 *}$ and Yoon Kil Chang ${ }^{2}$ \\ ${ }^{1}$ Professora Adjunta; Departamento de Química; FURG - Universidade do Rio Grande; C. P. 474; 96201-900; \\ Rio Grande - RS - Brazil. ${ }^{2}$ Professor Associado; Departamento de Tecnologia de Alimentos; UNICAMP - \\ Universidade Estadual de Campinas; C. P. 6121; 13083-970; Campinas - SP - Brazil
}

\begin{abstract}
The main objective of this work was to determine the influence of formulation on the stability of bread dough during frozen storage. Bread doughs containing gluten and trehalose were submitted to mechanical freezing at $-30^{\circ} \mathrm{C}$ and stored frozen for 45 days. Two types of instant yeast were tested: (A) for sweet doughs and (B) for savoury doughs. Specific volume was significantly affected by the yeast type, type A showing better effect than type B. Frozen storage of the doughs negatively affected the specific volume, crumb hardness and technological score of the bread. The addition of $10 \%$ trehalose had a beneficial effect on the cell survival rate for both the yeasts.
\end{abstract}

Key words: Breadmaking, frozen dough, formulation

\section{INTRODUCTION}

Various factors are related to the quality of bread produced from frozen dough stored for long periods. The effect of freezing on the yeast properties has been widely studied. Several researches showed that the yeast viability is strongly influenced by the fermentation process prior to freezing (Hino et al., 1987; Báguena et al., 1991; Salas-Mellado, 1992), by freezing and thawing velocities (Gélinas et al., 1993; Gehrke et al., 1992; Autio and Sinda, 1992; Murakami et al., 1994) and by the duration of frozen storage (Berglund and Shelton, 1993; Wang and Ponte, 1995). The yeast type and its properties also play important role in yeast viability and in the quality of the product (Gélinas et al., 1993; Murakami et al., 1994; Van Dam and Hille, 1992; Inoue et al., 1994). In commercial productions of frozen dough, higher amounts of yeast are used, and also no-time bakery procedures, low preparation temperatures and tunnel freezing, in order to minimize the above mentioned effects.

The influence of storage time and the structural conditions of the gluten are important factors in the quality of products made from frozen dough. The structure of the gluten protein matrix appears to break up during prolonged storage and repeated cycles of freezing/thawing (Berglund et al., 1991; Wang and Ponte, 1995; Autio and Sinda, 1992), resulting in a weakening of the strength properties of the dough, loss of gas retention and deterioration of product quality (Inoue and Bushuk, 1991; Inoue and Bushuk, 1992; Autio and Sinda, 1992; Inoue et al., 1994; Czuchajowska and Paszczyñska, 1996). The extent of these adverse effects can be reduced by using very strong flours (Inoue and Bushuk, 1992), by the addition of gluten (Wang and Ponte, 1994; Wang and Ponte, 1995) or by the use of additives such as sodium or calcium stearoyl lactilate (SSL and CSL) or the diacetyl-tartrate ester of monoglyceride (DATEM) (Wolt and

\footnotetext{
* Author for correspondence
} 
D’Appolonia, 1984; Inoue et al., 1995; El-Hady et al., 1995; Nemeth et al., 1996).

Other studies have shown that the type and level of oxidant (Inoue and Bushuk, 1991; SalasMellado, 1992), enzymes (Himmelstein, 1984), mixing and moulding procedures (Dubois and Blockowsky, 1986; Gélinas et al., 1995; Nemeth et al., 1996) and a variety of other ingredients can influence the quality of frozen dough (Davis, 1981; Hosomi et al., 1992; Addo, 1997).

The capacity of the yeast to maintain a high fermentative capacity after long periods of low temperature storage is affected by technological and cellular parameters. Trehalose is considered to be an important physiological compound in the resistance of the yeast to cold (Almeida and Pais, 1996). This dissacharide has been related to the resistance of the yeast to various types of stress (Smewing, 1995; Oda et al., 1986; Gadd et al., 1987; Hino et al., 1990; Van der Plaat, 1974; Van Dijck et al., 1995; Hottinger et al., 1987; Mackenzie et al., 1988), demonstrating that a high intracellular trehalose content is an advantage for good stability to freezing/thawing after prolonged frozen storage. Research in the area by Méric et al. (1995) is of special interest. This group worked with bakery yeast, studying the evolution of trehalose during the preparation of frozen dough, finally concluding that a content of $4-5 \%$ (based on the dry weight of the yeast) at the moment of freezing, was sufficient to protect the yeast cells during the sequence of operations comprising prefermentation, freezing, frozen storage and thawing. This research led us to include this sugar in the formulation, for studying its protective effect on the yeast cells.

The objective of this study was to test the effect of trehalose and gluten as well as the type of yeast in the formulation of bread dough and its stability during frozen storage.

\section{MATERIALS AND METHODS}

\section{Raw material, ingredients and dough formulation}

The basic formulation (flour based) was the following: flour (100\%), water (farinographic absorption less than $2 \%$ ), instant dry yeast (1.3\%), salt $(2 \%)$, sugar $(2 \%)$, hydrogenated vegetable fat $(2 \%)$, sorbitan monooleate $(0.3 \%)$, ascorbic acid $(120 \mathrm{ppm})$, vital gluten (2 and 4\%) and $\mathrm{D}+$ trehalose (5 and $10 \%$, based on the yeast dry weight). In each basic formulation, two types of instant dry biological ferment (Fleischmann Royal) were used: for sweet dough (A) and for savoury dough (B). Seven formulations were chosen for each type of yeast (Table 1), varying in their gluten and trehalose contents, the standard formulation $\left(\mathrm{F}_{1}\right)$ containing no additives.

\section{Dough preparation, freezing, thawing and bread making}

For each formulation $(1 \mathrm{~kg})$, the ingredients were mixed in a laboratory dough mixer for 8 minutes, low speed to obtained optimal dough development. The dough was cut, kneaded and moulded into the form of $80 \mathrm{~g}$ buns, which were frozen in a mechanical tunnel with an air temperature of $-30^{\circ} \mathrm{C}$, until the temperature at the centre of the buns, measured by thermocouples was $-15^{\circ} \mathrm{C}$. The frozen dough buns were removed from the tunnel, and stored in polyethylene bags in a domestic freezer at $-15^{\circ} \mathrm{C}$ for 45 days.

After preparing the doughs, zero time samples, corresponding to the unfrozen dough, were removed. Further samples were removed after 1, 10 and 45 days of frozen storage, thawed in an incubator at $30^{\circ} \mathrm{C}$ for 1 hour, fermented at $30^{\circ} \mathrm{C}$ for 1 hour and 35 minutes and finally baked at $200^{\circ} \mathrm{C}$ for 20 minutes. The buns obtained were cooled at room temperature for at least one hour and evaluated with respect to volume, crumb hardness and scores for technological characteristics.

The flowsheet for the dough and bun preparations can be seen in Fig. 1.

\section{Determination of rheological characteristics of the dough}

After thawing, the dough samples at $0,1,10$ and 45 days were analysed using the TAXT-2 texturometer equipped with the probe used for the determination of extensibility according to Smewing (1995). The average area of the curve for 10 determinations of dough microextensibility was registered as the strength of the dough, expressed in newtons $(\mathrm{N})$.

\section{Determination of yeast viability}

After thawing, the number of viable yeasts was determined in the $0,1,10$ and 45 day dough samples, using the direct plate count method. The microbiological counts were carried out after 4 days of incubation at $30^{\circ} \mathrm{C}$ and the survival rate 
calculated from the number of viable yeasts after 45 days as a percentage (\%) of the number present on the first day.

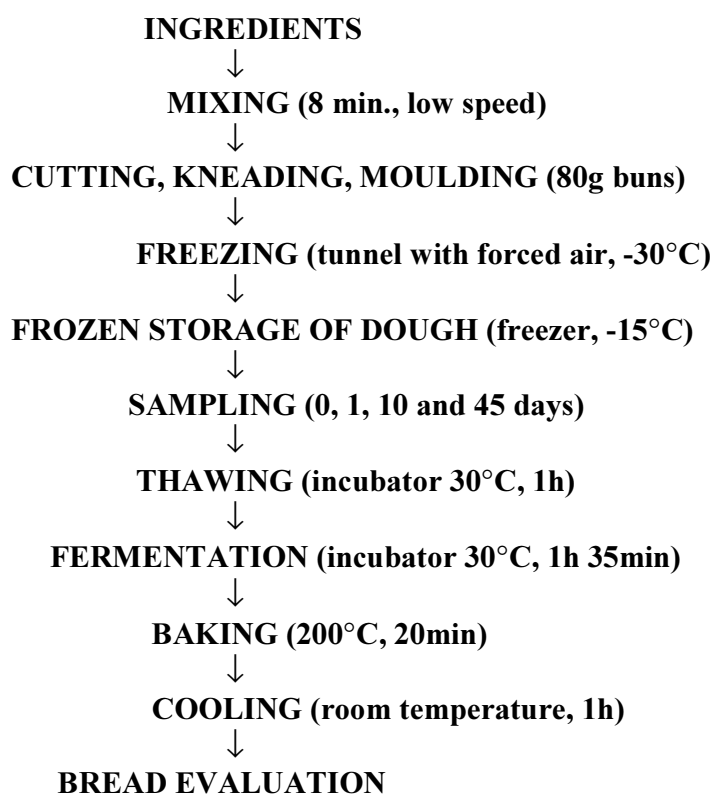

Figure 1 - Flowsheet for the dough and bun preparations
Determination of bread volume and hardness The specific volume of the buns obtained from the doughs after $0,1,10$ and 45 days of frozen storage was determined from the ratio of the volume obtained by seed displacement and the weight of the bread. Crumb hardness was determined by the compression of two $15 \mathrm{~mm}$ thick slices of bread, after 30 minutes cooling on the TAXT2 texturometer using the cylindrical 30 $\mathrm{mm}$ probe and expressing the results in newtons.

Determination of the technological characteristics scores of the bread

The scores were awarded to the bread for the external characteristics as follows: crust colour (10), break and shred (5), symmetry (5), and for the internal characteristics: crust characteristics (5), crumb colour (10), cellular crumb structure (10), and crumb texture (10), given a maximum total of 55 points, according to El-Dash (1978).

Table 1 - Formulations of bread dough for freezing

\begin{tabular}{cccccccc}
\hline Ingredients [\%] & $\mathbf{F}_{\mathbf{1}}$ & $\mathbf{F}_{\mathbf{2}}$ & $\mathbf{F}_{\mathbf{3}}$ & $\mathbf{F}_{\mathbf{4}}$ & $\mathbf{F}_{\mathbf{5}}$ & $\mathbf{F}_{\mathbf{6}}$ & $\mathbf{F}_{\mathbf{7}}$ \\
\hline Flour & 100.0 & 100.0 & 100.0 & 100.0 & 100.0 & 100.0 & 100.0 \\
Water & 58.9 & 58.9 & 58.9 & 58.9 & 58.9 & 58.9 & 58.9 \\
Yeast & 1.3 & 1.3 & 1.3 & 1.3 & 1.3 & 1.3 & 1.3 \\
Salt & 2.0 & 2.0 & 2.0 & 2.0 & 2.0 & 2.0 & 2.0 \\
Sugar & 2.0 & 2.0 & 2.0 & 2.0 & 2.0 & 2.0 & 2.0 \\
Fat & 2.0 & 2.0 & 2.0 & 2.0 & 2.0 & 2.0 & 2.0 \\
SMO & 0.3 & 0.3 & 0.3 & 0.3 & 0.3 & 0.3 & 0.3 \\
Ascorbic acid $^{\text {a }}$ & 120.0 & 120.0 & 120.0 & 120.0 & 120.0 & 120.0 & 120.0 \\
Vital gluten $^{\text {Trehalose }}$ & - & - & 2.0 & 2.0 & 2.0 & 4.0 & 4.0 \\
brehal $^{\text {b }}$ & - & 5.0 & - & 5.0 & 10.0 & 5.0 & 10.0 \\
\hline
\end{tabular}

SMO: Sorbitan monooleate; a: ppm; b: based on the yeast dry weight

\section{Statistical analysis}

Three effects were considered in this study:

a) Effect of formulation: Seven formulations studied for each yeast were those presented in Table 1.

b) Effect of the yeast: Two types of dry instant yeast were used, denominated as A for sweet dough, and B for savoury dough.

c) Effect of storage time: Dough samples and their respective bread were analysed after zero (non- frozen dough), 1, 10 and 45 days of frozen storage at $-15^{\circ} \mathrm{C}$.

The responses (dependant variables) were: specific volume, crumb hardness and technological characteristics scores of the bread. Extensibility and average curve area for 10 determinations on each dough sample were measured.

The results for specific volume, hardness and bread scores, as well as the data for extensibility were analysed statistically using the analysis of 
variance (Anova) applying a computer programme (SAS v. 5.0). The statistically significant differences $(\mathrm{p} \leq 0.05)$ between the different effects were determined by the LSD (Least Significant Difference) test.

\section{RESULTS AND DISCUSSION}

The analysis of variance of the values obtained, when the effects of formulation, yeast and storage time were considered, showed that all three effects were important. The effects of formulation, yeast and storage time were significant for the specific volume, crumb hardness and technological characteristics scores of the bread. No significant differences were detected for dough extensibility due to the effects of formulation, yeast and storage time.

\section{Effect of formulation}

When the average values for bread specific volume were compared, considering that formulation was the main effect, formulation F7 stood out from the others; others forming groups within which they did not differ from one another (Table 2). Highest value for specific volume was that obtained for the buns prepared using formulation F7, followed by those from formulations F6 and F4; formulations F5, F3, F1 and F2 resulted in lower values. These results show good correlation between specific volume and the amount of added gluten. Highest values for specific volume were obtained for the formulations with the highest amounts of added gluten. The formulations with no added gluten (F1 and F2) showed the lowest specific volumes. This demonstrated the beneficial effect of gluten. One interesting result was the lack of differentiation between formulations F6 and F4, despite different amounts of added gluten (4 and 2\% respectively). This could be related to the positive effect of trehalose, which, in both cases, was 5\%. Trehalose showed a protective effect on the yeast cells with respect to cold stress (Thevelein, 1984; Van Laere, 1989), which could have let the yeasts in the doughs containing trehalose more resistant to the effects of freezing, thus producing bread with higher specific volumes than those containing no trehalose.

When the average values for bread hardness were compared for all the formulations including the values for both types of yeast, there were significant differences for crumb hardness between the different dough formulations. The formulations with high levels of added gluten showed the best performance with respect to crumb hardness, showing lower values (Table 2). Formulations F4 and F3, with low levels of gluten, presented intermediate hardness values and formulations F1 and F2, with no gluten, showed the highest values for crumb hardness. Observing the values for specific volume and hardness together (Fig. 2), a direct interrelation between the formulations with added gluten and trehalose (F6 and F7) was found, showing the highest values for specific volume and lower values for hardness. The beneficial effect of gluten to the dough has been observed by other researchers (Inoue and Bushuk, 1991; Wang and Ponte, 1994; Czuchajowska and Paszczyñska, 1996). The behaviour of formulation F5 deserved some attention, since despite a high level of trehalose, it did not show any clearly beneficial effect, being placed in an intermediary position between the rich formulations (F6 and F7) and the poor formulations (F1 and F2).

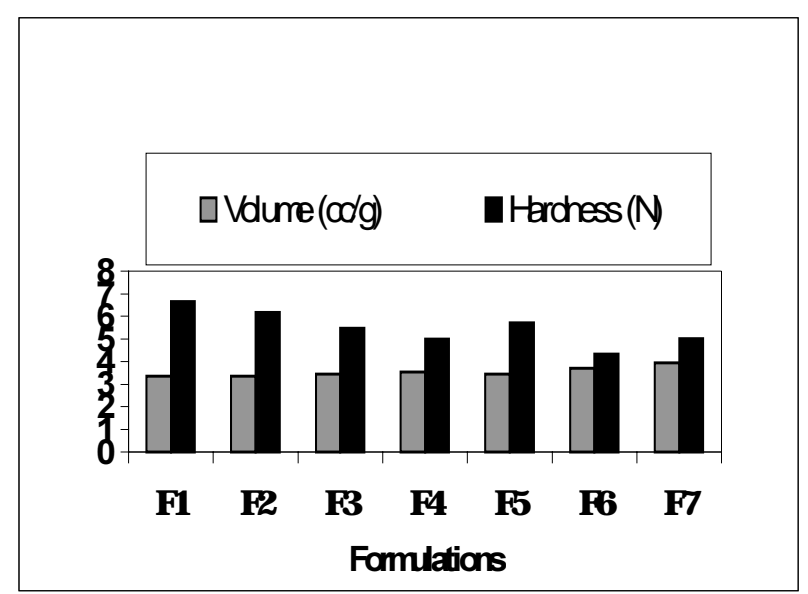

Figure 2 - Effect of dough formulation in bread specific volume and hardness

\section{Effect of yeast}

The specific volume of the bread was the only response affected by the type of yeast used. The buns made with the yeast for sweet dough (A) showed a mean average specific volume (3.70 $\mathrm{mL} / \mathrm{g}$ ) higher than buns prepared with the yeast for savoury dough $(3.37 \mathrm{~mL} / \mathrm{g})$. This may have been due to the fact that yeast $\mathrm{A}$, being a yeast suitable for sweet dough, with characteristics of osmotolerance, could have better resisted the 
operations of freezing, thawing and frozen storage. The good performance of dry active yeasts has been discussed by El-Hady et al. (1996), who showed that the dried yeast was more stable during frozen storage for 12 weeks, when compared to compressed yeasts.

Table 2 - Average values ${ }^{\mathrm{a}}$ for specific volume and crumb hardness for the different formulations.

\begin{tabular}{ccc}
\hline Formulation & $\begin{array}{c}\text { Specific } \\
\text { volume [cc/g] }\end{array}$ & $\begin{array}{c}\text { Crumb } \\
\text { hardness [N] }\end{array}$ \\
\hline F1 & $3.36 \mathrm{a}$ & $6.53 \mathrm{a}$ \\
F2 & $3.35 \mathrm{a}$ & $6.04 \mathrm{a}$ \\
F3 & $3.43 \mathrm{a}$ & $5.37 \mathrm{~b}$ \\
F4 & $3.54 \mathrm{~b}$ & $4.90 \mathrm{~b}, \mathrm{c}$ \\
F5 & $3.44 \mathrm{a}$ & $5.59 \mathrm{~b}$ \\
F6 & $3.71 \mathrm{~b}$ & $4.24 \mathrm{~b}, \mathrm{c}$ \\
F7 & $3.93 \mathrm{c}$ & $4.91 \mathrm{~b}, \mathrm{c}$ \\
\hline
\end{tabular}

${ }^{a}$ Average values for each formulation, considering both yeasts $\mathrm{A}$ and $\mathrm{B}$.

The averages with the same letter do not present significant differences ( $p \leq 0.05$, LSD)

The crumb hardness and bread scores, as also the dough extensibility, were not influenced by the type of yeast used, since the results of this effect did not present statistically significant differences.

\section{Effect of storage time}

The specific volume, crumb hardness and technological characteristics scores were influenced by the time of frozen storage of the doughs. The dough extensibility was not influenced by this effect. A significant reduction in specific volume was observed for the bread elaborated with frozen dough stored for 1, 10 and 45 days when compared with the non-frozen dough, as can be seen in Table 3 .

Table 3 - Average values ${ }^{\mathrm{a}}$ for specific volume, hardness and bread scores with respect to storage time.

\begin{tabular}{cccc}
\hline $\begin{array}{c}\text { Storage } \\
\text { Time } \\
\text { [days] }\end{array}$ & $\begin{array}{c}\text { Specific } \\
\text { Volume } \\
{[\mathbf{c c} / \mathbf{g}]}\end{array}$ & $\begin{array}{c}\text { Crumb } \\
\text { Hardness } \\
{[\mathbf{N}]}\end{array}$ & $\begin{array}{c}\text { Bread } \\
\text { Score }\end{array}$ \\
\hline $0^{\mathrm{b}}$ & $4.17 \mathrm{a}$ & $4.04 \mathrm{a}$ & $45.85 \mathrm{a}$ \\
1 & $3.70 \mathrm{~b}$ & $4.80 \mathrm{a}$ & $45.32 \mathrm{a}$ \\
10 & $3.47 \mathrm{c}$ & $5.96 \mathrm{~b}$ & $44.67 \mathrm{~b}$ \\
45 & $2.82 \mathrm{~d}$ & $6.66 \mathrm{~b}$ & $43.91 \mathrm{~b}$ \\
\hline
\end{tabular}

${ }^{a}$ Average values for buns from all the formulations with both yeasts.

non-frozen dough

Values with the same letter did not present significant differences $(p \leq 0.05$, LSD)
The average values for specific volume showed a progressive decrease during frozen storage, signifying a loss of bread quality. On the other hand, an increase in crumb hardness with increasing storage time was observed for all the formulations studied. This has also been observed by Berglund and Shelton, (1993), who studied doughs frozen at $-23^{\circ} \mathrm{C}$ and stored for 20 weeks. They showed that long storage periods resulted in an increase in the values for hardness, associated with a decrease in bread volume.

The storage time also influenced the scores conferred on the buns for their technological quality. A fall in the scores and an increase for hardness with storage time was noted. The statistical analysis demonstrated that the freezing process and frozen storage for one day had little effect on these characteristics, because there was no significant difference between the non-frozen dough and that frozen and stored frozen for one day. The highest changes occurred between 1 and 10 days of storage; further storage up to 45 days not greatly affected the hardness characteristics and bread scores when compared with the values obtained for doughs stored frozen for 10 days.

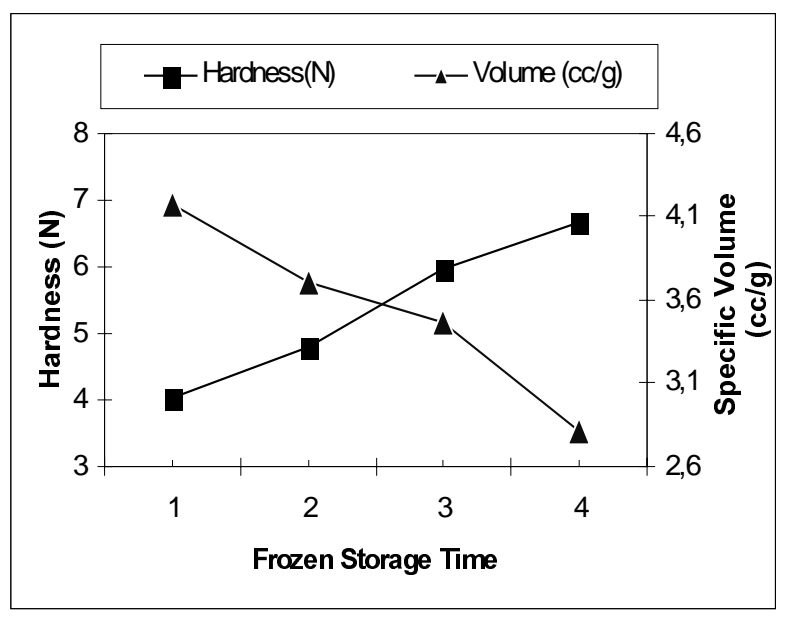

Figure 3 - Effect of storage time in bread specific volume and crumb hardness 1: non-frozen dough; 2: 1 day of frozen storage; 3: 10 days of frozen storage; 4: 45 days of frozen storage

Fig. 3 shows the results for specific volume and bread hardness with respect to storage time, showing clearly the decrease in specific volume and increase in hardness of the bread, resulting in a fall in bread quality as a result of the loss of 
stability of the doughs during frozen storage, which could partly be due to the effect of the growth of ice crystals in the doughs during frozen storage (Reid, 1983).

Dough extensibility as measured by the texturometer showed no significant differences with any of the effects studied. These results seem to show that the chosen methodology was not the most appropriate, since the test was not sensitive to the rheological changes which must have occurred in the doughs due to the formulations and frozen storage.

\section{Yeast Viability}

The cell survival rates in doughs elaborated with yeasts A and B after 45 days of storage are shown in Table 4. It could be seen that the cell survival rates were higher in the doughs elaborated with yeast $A$ than in those elaborated with yeast $B$, demonstrating that the yeast for sweet dough (A) was more resistant to freezing and frozen storage than the yeast for savoury dough (B), as already mentioned in item 3.2. The better response of yeast $A$ could be due to higher osmotolerance as compared to yeast B on account of being adapted for sweet dough, as related by Van Dam and Hille (1992). The osmotolerance property allowed yeast A to present a greater resistance against freezing, thawing and frozen storage.

Table 4 - Yeast counts ${ }^{\mathrm{d}}$ and survival rates in the different formulations.

\begin{tabular}{|c|c|c|c|}
\hline Formulations & $\begin{array}{c}\text { Zero day } \\
\text { Count } \\
{\left[\begin{array}{lll}\mathbf{x} & 10^{4}\end{array}\right]}\end{array}$ & $\begin{array}{c}\text { Count on } \\
\text { Day } 45 \\
{\left[\begin{array}{lll}x & 10^{4}\end{array}\right]} \\
\end{array}$ & $\begin{array}{c}\text { Survival } \\
\text { Rate } \\
{[\%]}\end{array}$ \\
\hline $\mathrm{F} 1 \mathrm{~A}^{\mathrm{a}}$ & 923 & 744 & 84 \\
\hline $\mathrm{F} 1 \mathrm{~B}^{\mathrm{a}}$ & 842 & 546 & 65 \\
\hline $\mathrm{F} 3 \mathrm{~A}^{\mathrm{a}}$ & 888 & 740 & 83 \\
\hline $\mathrm{F}^{3} \mathrm{~B}^{\mathrm{a}}$ & 853 & 533 & 62 \\
\hline $\mathrm{F} 2 \mathrm{~A}^{\mathrm{b}}$ & 958 & 756 & 79 \\
\hline $\mathrm{F} 2 \mathrm{~B}^{\mathrm{b}}$ & 841 & 574 & 68 \\
\hline $\mathrm{F} 4 \mathrm{~A}^{\mathrm{b}}$ & 950 & 763 & 80 \\
\hline $\mathrm{F} 4 \mathrm{~B}^{\mathrm{b}}$ & 866 & 615 & 71 \\
\hline F6A $A^{b}$ & 963 & 616 & 64 \\
\hline $\mathrm{F}^{6} \mathrm{~B}^{\mathrm{b}}$ & 808 & 426 & 53 \\
\hline $\mathrm{F} 5 \mathrm{~A}^{\mathrm{c}}$ & 1033 & 957 & 93 \\
\hline $\mathrm{F} 5 \mathrm{~B}^{\mathrm{c}}$ & 907 & 903 & 99 \\
\hline F7A $A^{c}$ & 798 & 746 & 93 \\
\hline $\mathrm{F} \mathrm{B}^{\mathrm{c}}$ & 808 & 740 & 92 \\
\hline
\end{tabular}

A: yeast for sweet dough; B: yeast for savoury dough; a: no added trehalose; b: $5 \%$ of trehalose; c: $10 \%$ of trehalose; d: c.f.u./g dough
As can be observed from Fig 4, that register the yeast survival rate have been presented by the different bread formulations arranged in increasing trehalose content, formulations containing yeast type $\mathrm{B}$ showed a direct relation between the two factors which was not shown by yeast type A formulations. The fall in microbial counts after freezing and frozen storage has been reported by others also (Berglund and Shelton, 1993; Wang and Ponte, 1995).

The formulations containing no trehalose (F1 and F3) presented the lowest cell survival rates, and those with $10 \%$ trehalose the highest. Of the formulations with low amounts of trehalose, only formulation 6 showed a much lower survival rate, however there was no obvious reason for this. It would be necessary to measure gas production by the yeasts to elucidate why a high gluten content negatively influenced cell growth in this formulation.

The yeast survival rates in doughs prepared with both types of yeast (A and B) were higher than $90 \%$ with $10 \%$ trehalose in the formulation, showing the protective effect of this dissacharide to the cold stress experienced by the yeast cells. This has also been reported by D'Amore et al. (1991), Oda et al. (1986) and Van Dijk et al. (1995).

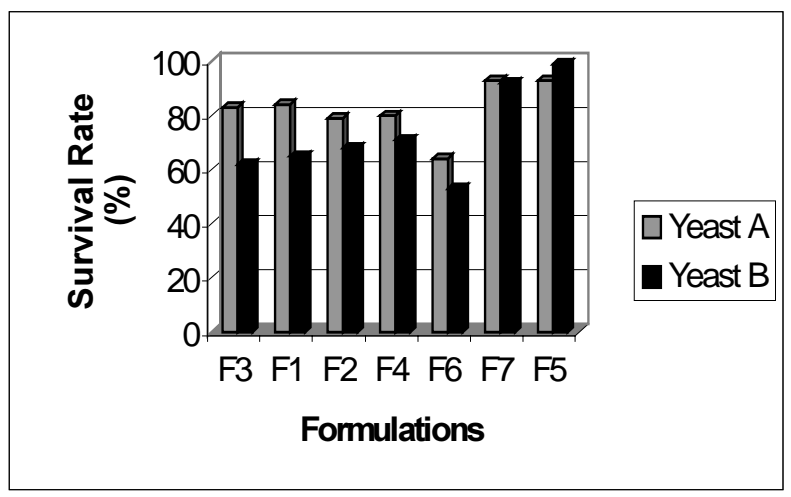

Figure 4 - Effect of dough formulation in yeast survival rate for yeast type $\mathrm{A}$ and $\mathrm{B}$

\section{CONCLUSIONS}

The dough formulation significantly influenced the specific volume and crumb hardness of the bread. The buns prepared with formulation F7, containing high levels of gluten and trehalose, were those which presented the highest specific volume, 
significantly different from those made with the other formulations, which presented smaller values.

The addition of $10 \%$ trehalose in dough formulation produced higher survival yeast rates after frozen storage of 45 days for both yeast type used in this work. High levels (4\%) of gluten showed good perfomance on bread crumb hardness. The type of yeast significatively affected the specific volume and the yeast for sweet dough showed better perfomance when compared with yeast for savoury dough. Frozen storage time of 45 days resulted in decrease of bread specific volume and bread score of technological characteristics and an increase of bread crumb hardness.

\section{ACKNOWLEDGEMENTS}

The authors are grateful to FAPESP for the financial assistance and to Dr Paul Kinas of the Department of Mathematics and Statistics of FURG for help in the statistical treatment of the data.

\section{RESUMO}

O principal objetivo deste trabalho foi determinar a influência da formulação na estabilidade da massa de pão durante a estocagem congelada. As massas para pão contendo glúten Vital e trealose foram submetidas a congelamento mecânico de $30^{\circ} \mathrm{C}$ e estocadas na forma congelada por 45 dias. Foram testados dois tipos de leveduras instantâneas: (A) para massas doces, e (B) para massas salgadas. Foram avaliados na massa, os efeitos da formulação, tipo de levedura e a estocagem congelada, pelas características de extensibilidade e a contagem de leveduras viáveis, e no pão, pelo volume específico, a dureza do miolo e as características tecnológicas. Somente o volume específico foi influenciado pelo tipo de levedura, mostrando o tipo A um melhor efeito do que o tipo B. A estocagem congelada influenciou negativamente o volume específico, a dureza do miolo e a pontuação tecnológica do pão. A adição de $10 \%$ de trealose mostrou um efeito benéfico na taxa de sobrevivência celular para ambos tipos de leveduras.

\section{REFERENCES}

Addo, K. (1997), Effects of honey type and level on the baking properties of frozen wheat flour doughs. Cereal Food World, 42 : (1), 36-40.

Almeida, M. J. and Pais, C. (1996), Leavening ability and freeze tolerance of yeast isolated from traditional corn and rye bread doughs. Applied Environmental Microbiology, 62, 4401-4404.

Autio, K. and Sinda, E. (1992), Frozen doughs rheological changes and yeast viability. Cereal Chemistry, 69, 409-413.

Báguena, R.; Soriano, M. D.; Martinez-Anaya, M. A.; Benedito de Barber, C. (1991), Viability and performance of pure yeast strains in frozen doughs. Journal of Food Science, 56, 1690-1698.

Berglund, P. T.; Shelton, D. R.; Freeman, T. P. (1991), Frozen bread dough ultrastructure as affected by duration of frozen storage and freeze-thaw cycles. Cereal Chemistry, 68, 105-107.

Berglund, P. T. and Shelton, D. R. (1993), Effect of frozen storage duration on firming properties of breadbaked from frozen doughs. Cereal Foods World, 38, 89-93.

Czuchajowska, Z. and Paszczyñska, B. (1996), Is wet gluten food for baking? Cereal Chemistry, 73 : (4), p.483-489.

D'amore, T.; Crumplein, R. and Stenvart, G. G. (1991), The involvement of trehalose in yeast stress tolerance. Journal of Industrial Microbiology, 7, 191-196.

Davis, E. W. (1981), Shelf-life studies on frozen doughs. Baker's Digest, 55 : (3), 12-16.

Dubois, D. K. and Blockcolsky, D. (1986), Frozen bread dough, effect of dough mixing and thawing methods. American Institute of Baking, 8, 1-7.

El-Dash, A. (1978), Standardized mixing a fermentation procedure for experimental baking test. Cereal Chemistry, 55, 336.

El-Hady, E. A.; El-Samahy, S. K.; Seibel, W. and Meyer, D. (1995), Mikrostruktur von gefrosteten brotteigen. Getreide Mehl und Brot, 49, 40-46.

El-Hady, E. A.; El-Samahy, S. K.; Seibel, W. and Brümmer, J. M. (1996), Changes in gas production and retention in non prefermented frozen wheat doughs. Cereal Chemistry, 73 : (4), 472-477.

Gadd, G. M.; Chalmers, K. and Reed, R. H. (1987), The role of trehalose in dehydration resistance of Saccharomyces cerevisiae. FEMS Microbiology Review, 48, 249-254.

Gehrke, H. H.; Pralle, K. and Deckwer, W. D. (1992), Freeze drying of microorganisms - Influence of cooling rate on survival. Food Biotechnology, 6 : (1), 35-49.

Gélinas, P.; Lagimonière, M. and Dubord, C. (1993), Baker's yeast sampling and frozen dough stability. Cereal Chemistry, 70, 219-225. 
Gélinas, P.; Deaudelin, I. and Grenier, M. (1995), Frozen dough: Effects of dough shape, water content and sheeting-molding conditions. Cereal Foods World, 40 : (3), 124-126.

Himmelstein, A. (1984), Enzyme treatment of flour. Will it help frozen and retarded dough? Bakers Digest, 58: (5), 8-12.

Hino, A.; Takano, H. and Tanaka, Y. (1987), New freeze-tolerant yeast for frozen dough preparations. Cereal Chemistry, 64, 269-275.

Hino, A.; Mihara, K.; Nakashima, K. and Takano, H. (1990), Trehalose levels and survivals ratio of freezetolerant versus freeze-sensitive yeasts. Applied and Environmental Microbiology, 56, 1386-1391.

Hosomi, K.; Nishio, K. and Matsumoto, H. (1992), Studies on frozen dough baking. I. Effects of egg yolk and sugar ester. Cereal Chemistry, 69, 82-92.

Hottinger, T.; Boller, T. and Wiemken, A. (1987), Rapid changes of heat and desiccation tolerance correlated with changes of trehalose content in Saccharomyces cerevisiaie cells subjected to temperature shifts. FEBS Letters, 220, 113-115.

Inoue, Y. and Bushuk, W. (1991), Studies on frozen doughs. I. Effects of frozen storage and freeze-thaw cycles on baking and rheological properties. Cereal Chemistry, 68, 627-631.

Inoue, Y. and Bushuk, W. (1992), Studies on frozen doughs. II. Flour quality requirements for bread production from frozen dough. Cereal Chemistry, 69, 423-428.

Inoue, Y.; Sapirstein, H. D.; Takayanagi, S. and Bushuk, W. (1994), Studies on frozen doughs. III. Some factors involved in dough weakening during frozen storage and thaw-freeze cycles. Cereal Chemistry, 71, 118-121.

Inoue, Y.; Sapirstein, H. D. and Bushuk, W. (1995), Studies on frozen doughs. IV. Effect of shortening systems on baking and rheological properties. Cereal Chemistry, 72 : (2), 221-226.

Mackenzie, K. F.; Singh, K. K. and Brown, A. D. (1988), Water stress plating hypersensitivity of yeast: Protective role of trehalose in Saccharomyces cerevisiae. Journal of Genetic Microbiology, 134, 1661-1666.

Méric, L.; Lambert-Guilois, S.; Neyreneuf, O. and Richard-Molard, D. (1995), Cryoresistance of Baker's yeast Saccharomyces cerevisiae in frozen dough: Contribution of cellular trehalose. Cereal Chemistry, 72 : (6), 609-615.

Murakami, Y.; Hahn, Y. S.; Yokoigawa, K.; Endo, K. and Kawai, H. (1994), Induction of freeze-sensitive mutants from a freeze-tolerant yeast Torulaspora delbrueckii. Bioscience, Biotechnology and Biochemistry, 58 : (1), 206-207.
Nemeth, L. J.; Paulley, F. G. and Preston, K. R. (1996), Effects of ingredients and processing conditions on the frozen dough bread quality of a Canada Western Red Spring Wheat flour during prolonged storage. Food Research International, 29 : (7), 609-616.

Oda, Y.; Uno, K. and Ohta, S. (1986), Selection of yeasts for breadmaking by the frozen-dough method. Applied Environmental Microbiology, 52, 941-943.

Reid, D. S. (1983), Fundamental physicochemical aspects of freezing. Food Technology. April.

Salas-Mellado, M. M. (1992), Efeito de algumas variáveis do processo de panificação de massa congelada na estabilidade da massa estocada e na qualidade do pão. Dissertação (Mestrado em Tecnologia de Alimentos) - Faculdade de Engenharia de Alimentos, UNICAMP.

Sanderson, G. W. (1985), Yeast products for the baking. Cereal Foods World, 30 : (11), 770-774.

Smewing, J. (1995), The measurement of dough and gluten extensibility using the SMS/Kiefer rig and the TAXT2 Texture Analyser. Surrey, SMS Ltda.

Thevelein, J. M. (1984), Regulation of trehalose mobilization in fungi. Microbiology Review, 48, 42-59.

Van Dam, H. W. and Hille, D. R. (1992), Yeast and enzymes in breadmaking. Cereal Foods World, 37 : (3), 245-251.

Van Der Plaat, J. B. (1974), Cyclic 3', 5'-adenosine monophosphate stimulates trehalose degradation. Biochemistry Biophysics Research Commitee, 56, 580-587.

Van Dijck, P.; Colavizza, D.; Smet, P. and Thevelein, J. M. (1995), Differential importance of trehalose in stress resistance in fermenting and non fermenting Saccharomyces cerevisiae cells. Applied and Environmental Microbiology, 61 : (1), 109-115.

Van Laere, A. (1989), Trehalose. Reserve and / or stress metabolite? FEMS Microbiology, 63, 201-210.

Wang, Z. J. and Ponte Jr., J. G. (1994), Improving frozen dough qualities with the addition of Vital wheat gluten. Cereal Foods World, 39: (7), 500-503.

Wang, Z. J. and Ponte Jr., J. G. (1995), Storage stability of gluten-fortified frozen dough. Cereal Foods World, 40 : (11), 827-831.

Wolt, M. J. and D'Appolonia, B. L. (1984), Factors involved in the stability of frozen dough. II. The effect of yeast type, flour type, and dough additives on frozen-dough stability. Cereal Chemistry, 61, 213-221. 